\title{
P53 AND RB TUMOR SUPPRESSOR GENE ALTERATIONS IN GASTRIC CANCER
}

Rejane Mattar, Suely Nonogaki, Cleonice Silva, Venancio Alves, and Joaquim J. Gama-Rodrigues

MATTAR R et al. p53 and $R b$ tumor suppressor gene alterations in gastric cancer. Rev. Hosp. Clín. Fac. Med. S. Paulo 59(4):172-180, 2004.

Inactivation of tumor suppressor genes has been frequently observed in gastric carcinogenesis. Our purpose was to study the involvement of $p 53, A P C, D C C$, and $R b$ genes in gastric carcinoma.

METHOD: Loss of heterozygosity of the $p 53, A P C, D C C$ and $R b$ genes was studied in 22 gastric cancer tissues using polymerase chain reaction; single-strand conformation polymorphism of the $p 53$ gene exons 5-6 and exons 7-8 was studied using ${ }^{35} \mathrm{~S}$-dATP, and p53 expression was detected using a histological immunoperoxidase method with an anti-p53 clone.

RESULTS AND DISCUSSION: No loss of heterozygosity was observed in any of these tumor suppressor genes; homozygous deletion was detected in the $R b$ gene in $23 \%(3 / 13)$ of the cases of intestinal-type gastric carcinoma. Eighteen $(81.8 \%)$ cases showed band mobility shifts in exons 5-6 and/or 7-8 of the $p 53$ gene. The presence of the p53 protein was positive in gastric cancer cells in 14 cases $(63.6 \%)$. Normal gastric mucosa showed negative staining for p53; thus, the immunoreactivity was likely to represent mutant forms. The correlation of band mobility shift and the immunoreactivity to anti-p53 was not significant $(P=.90)$. There was no correlation of gene alterations with the disease severity.

CONCLUSIONS: The inactivation of $R b$ and $p 53$ genes is involved in gastric carcinogenesis in our environment. Loss of the $R b$ gene observed only in the intestinal-type gastric cancer should be further evaluated in association with Helicobacter pylori infection. The p53 gene was affected in both intestinal and diffuse histological types of gastric cancer.

KEY WORDS: Gastric cancer. APC. DCC. Rb. p53.

Gastric cancer is a heterogeneous pathology, being classified by Laurén $(1965)^{1}$ into 2 general subtypes: intestinal (differentiated) and diffuse (undifferentiated). Intestinal-type gastric cancer may or may not be preceded by preneoplastic lesions; it is more prevalent in older individuals and in certain geographical areas where there is a high incidence of gastric carcinoma, such as in Japan. ${ }^{2}$

The differences between these two histological subtypes occur also at the molecular level, suggesting different genetic pathways. The intestinal-type gastric carcinoma presents tumor suppressor gene alterations similar to colorectal tumors and distinct from diffuse-type gastric cancer. ${ }^{3}$

An accumulation of multiple genetic and epigenetic alterations of oncogenes, tumor suppressor genes, DNA repair genes, cell cycle regula-

From the Department of Gastroenterology, Hospital das Clínicas, Faculty of Medicine, University of São Paulo and Division of Pathology, Adolfo Lutz Institute - São Paulo/ SP, Brazil.

E-mail: rejanemattar@hotmail.com Received for publication on November 05, 2003. tors, cell adhesion molecules, and growth factor/receptor systems are involved throughout the course of the multistep conversion of normal epithelial cells to clinical gastric cancer. ${ }^{4}$

In gastric cancer, $p 53$ gene alterations have been observed in both histological subtypes, ${ }^{5}$ being correlated with node-positive cancer, ${ }^{6,7}$ depth of tumor invasion, ${ }^{8}$ and poor survival..$^{9,10}$ The p53 protein is a transcriptional factor that arrests the cell cycle in the G1 phase when DNA is damaged ${ }^{11}$ by inducing the expression of the p21 protein, an inhibitor of Cdk kinase and 
PCNA. ${ }^{12,13}$ Thus, damaged DNA can not replicate, allowing time for the repair system to act. ${ }^{11}$ If this system fails, p53 induces apoptosis by transactivation of the bax gene. ${ }^{14}$

The loss of heterozygosity $(\mathrm{LOH})$ and the loss of expression of the $D C C$ gene have been more frequently found in the intestinal-type gastric cancer ${ }^{15-}$ 17 and have often been encountered $(35.3 \%)$ in gastric cancer in stage III and IV. Thus, in gastric cancer, LOH of the $D C C$ gene was a late event associated with malignant progression. ${ }^{15,18}$ The DCC gene, located on the long arm of chromosome $18,{ }^{19}$ encodes a netrin-1 receptor component with functions in cell migration, ${ }^{20} \mathrm{G} 2 / \mathrm{M}$ cell cycle arrest, and apoptosis. ${ }^{21}$

The mutated $A P C$ germline gene on chromosome $5 q 21$ is responsible for the inheritance of familial adenomatous polyposis; in addition, it was somatically altered in sporadic colorectal cancer patients. ${ }^{22}$ In gastric cancer, the incidence of allelic deletions of $A P C$ was significantly higher in the intestinal phenotypes than in the diffuse phenotypes. ${ }^{23}$ Furthermore, APC down-regulates the proto-oncogene $\beta$ catenin that is critical for intercellular adhesion and has linked colorectal carcinogenesis to the Wnt-signal transduction pathway. ${ }^{24}$ Increased $\beta$-catenin mRNA levels were significantly more frequent in intestinal-type gastric cancers as compared with the diffuse-type gastric cancers. APC gene mutations found in these cases of intestinal-type gastric cancer were associated with the increase of $\beta$-catenin mRNA levels. ${ }^{25}$

Loss of the retinoblastoma $(R b)$ gene has been associated with esophageal tumorigenesis, ${ }^{26}$ and at a lower rate to gastric cancer development. ${ }^{17}$ However, more recent reports have shown that Helicobacter pylori (H. pylori) infection generated gastric cancer through $p 53-R b$ tumor-suppressor system mutation and telomerase reactivation. ${ }^{27}$ The $R b$ gene encodes a nuclear protein that acts as a cell cycle control checkpoint at the G1 phase. $^{28}$

The purpose of our study was to further analyze the involvement of $p 53$, $A P C, D C C$, and $R b$ tumor suppressor genes in gastric carcinoma cases.

\section{MATERIALSAND METHOD}

Gastric cancer tissues and corresponding leukocytes were obtained from 22 patients after surgical treatment during the period of 1996 to 1997 at the Hospital of Clinics, Department of Gastroenterology, and were immediately frozen in liquid nitrogen and stored prior to DNA extraction. The average age of the patients (18 men, 4 women) was $63.4+14.3$ years. The tumors were classified as intestinal and diffuse types according to Láuren1; 13 cases were of the intestinal type and 9 cases were of the diffuse type. The TNM stage grouping was performed according to the criteria of the Japanese Classification of Gastric Carcinoma. ${ }^{29}$

\section{DNA extraction}

DNA was extracted from the thawed cancer tissue and peripheral leucocytes using a phenol-chloroform method ${ }^{30}$ and stored at $4{ }^{\circ} \mathrm{C}$ until use.

\section{Polymerase Chain Reaction (PCR)}

One microgram or $300 \mathrm{ng}$ of genomic DNA was used as a template in a reaction volume of $50 u \mathrm{~L}$, containing 50 pmol of each primer (Table 1), $200 u \mathrm{M}$ of each dNTP and $2.5 \mathrm{U}$ of Taq DNA polymerase (Gibco BRL, Gaithersburg, MD, USA). The PCR was performed in a 2400 GeneAmp PCR system (Perkin Elmer, Branchburg, NJ, USA). Amplification was performed for 35 cycles at an annealing temperature of $68{ }^{\circ} \mathrm{C}$ for $A P C,{ }^{31} 62{ }^{\circ} \mathrm{C}$ for $p 53,{ }^{32}$ $55^{\circ} \mathrm{C}$ for $D C C,{ }^{31}$ and $57{ }^{\circ} \mathrm{C}$ for $R b$ D13S270. ${ }^{33}$ The amplification conditions for $R b$ intron 1 were 40 cycles in 2 steps $\left(94^{\circ} \mathrm{C}\right.$ for $1 \mathrm{~min}$ and $50{ }^{\circ} \mathrm{C}$ for $1 \mathrm{~min}$ ), followed by 1 extension step at $72{ }^{\circ} \mathrm{C}$ for $5 \mathrm{~min}$; inclusion of $10 \%$ dimethyl sulfoxide (DMSO) was necessary for generating the $180 \mathrm{bp}$ fragment. ${ }^{34} \mathrm{~A}$ second primer pair that spans the same locus was used in the cases where the PCR product was absent from the carcinoma DNA template when compared with a strong product from the paired constitutional DNA template.

\section{Restriction fragment length poly- morphism analysis}

Products of the PCR $(\sim 45 u \mathrm{~L})$ were digested with $60 \mathrm{U}$ of $M s p \mathrm{I}(D C C)$ (Stratagene, La Jolla, CA, USA) and $R s a \mathrm{I}(A P C)$ (Stratagene, La Jolla, CA, USA), $15 \mathrm{U}$ of BamHI $(R b)$ (Stratagene, La Jolla, CA, USA), and $8 \mathrm{U}$ of AccII (p53) (Amersham Life Science, Cleveland, $\mathrm{OH}, \mathrm{USA}$ ) at $37^{\circ} \mathrm{C}$ overnight. The DNA fragments were separated by electrophoresis on $4 \%$ low-meltingpoint agarose gels. For VNTR, $R b$ (D13S270), and after MspI digestion, PCR products were separated on $3 \%$ low-melting-point agarose gels.

\section{PCR Analysis of Single-Strand Con- formation Polymorphism}

Genomic DNA (300 - 500 ng) was used as a template in a reaction volume of $25 \mu \mathrm{L}$ containing $50 \mathrm{pmol}$ of each primer (Table 1), $200 \mu \mathrm{M}$ of deoxynucleotide triphosphate (dNTP), ${ }^{35} \mathrm{~S}$-dATP $(0.5 \mu \mathrm{L})$, and $2.5 \mathrm{U}$ of Taq DNA polymerase (Amersham Biosciences). Exons 5-6 and 7-8 of the p53 gene were amplified in 35 cycles according to the following schedule: $94{ }^{\circ} \mathrm{C}$ for $30 \mathrm{~s}, 63{ }^{\circ} \mathrm{C}$ for $50 \mathrm{~s}$, and $72{ }^{\circ} \mathrm{C}$ for $1 \mathrm{~min}$. The elongation step was done at $72{ }^{\circ} \mathrm{C}$ for $10 \mathrm{~min}$. Amplification products were diluted 5-fold in $0.1 \%$ SDS, 
Table 1 - Primer sets used in polymerase chain reaction analysis for loss of heterozygosity (PCR-LOH) and polymerase chain reaction analysis for single-strand conformation polymorphism (PCR-SSCP) analysis.

\begin{tabular}{|c|c|c|c|}
\hline Priming region & Amplicon size (bp) & Polymorphism type & Primer Sequences \\
\hline$\overline{A P C}$ exon 11 & 133 & $R s a \mathrm{I}$ & $\begin{array}{l}\text { 5'-GGACTACAGGCCATTGCAGAA-3' } \\
\text { 5'-GGCTACATCTCCAAAAGTCAA-3', }\end{array}$ \\
\hline p53 exon 4 & 259 & $A c c \mathrm{II}$ & $\begin{array}{l}\text { 5'-AATGGATGATTTGATGCTGTCCC-3' } \\
\text { 5'-CGTGCAAGTCACAGACTTGGC-3' }\end{array}$ \\
\hline $\mathrm{DCC}^{*}$ & $210-150$ & $V N T R$ & $\begin{array}{l}\text { 5'-GATGACATTTTCCCTCTAG-3', } \\
\text { 5'-GTGGTTATTGCCTTGAAAAG-3' }\end{array}$ \\
\hline DCC & 396 & $\mathrm{Msp} I$ & $\begin{array}{l}\text { 5'-TGCACCATGCTGAAGATTGT-3, } \\
\text { 5'-AGTACAACACAAGGTATGTG-3, }\end{array}$ \\
\hline$R b$ intron 1 & 180 & BamHI & $\begin{array}{l}\text { 5'-CAGGACAGCGGCCCGGAG-3' } \\
\text { 5'-CTGCAGACGCTCCGCCGT-3, }\end{array}$ \\
\hline$R b \mathrm{D} 13 \mathrm{~S} 270^{*}$ & $104-80$ & & $\begin{array}{l}\text { 5'- AGTGCCTGGGTATGAACGTG-3, } \\
\text { 5'- CTGGAAATGCCTTGGAAGGA-3, }\end{array}$ \\
\hline p53 exons 5-6 & 411 & & $\begin{array}{l}\text { 5'-GGAATTCCTCTTCCTACAGTACTCC-3', } \\
\text { 5'-GGAATTCAGTTGCAAACCAGACCTCA-3, }\end{array}$ \\
\hline p53 exons 7-8 & 677 & & $\begin{array}{l}\text { 5'-GGAATTCTCCTAGGTTGGCTCTGAC-3' } \\
\text { 5'-GGAATTCCTGCTTGCTTACCTCGCT-3' }\end{array}$ \\
\hline
\end{tabular}

* = Only to confirm homozygous deletion.

$10 \mathrm{mM}$ EDTA and were rediluted 1:2 in sequencing stop solution $(95 \%$ formamide, $20 \mathrm{mM}$ EDTA, $0.05 \%$ bromophenol blue, and $0.05 \%$ xylene cyanol); they were then heated at $90{ }^{\circ} \mathrm{C}$ for $5 \mathrm{~min}$, chilled on ice, and loaded onto a nondenaturing polyacrylamide gel $(6 \%$ acrylamide, 10\% glycerol, 1x TBE). Electrophoresis was carried out at $8 \mathrm{~W}$ at room temperature. After 4 hours of migration for exons 5-6 and 7 to 9 hours of migration for exons 7-8, the gels were dried and subjected to autoradiography using Kodak T-Mat G/RA film at $-80{ }^{\circ} \mathrm{C}$ with an intensifying screen. One sample of amplification product from blood was run together with tumor DNA amplification products. The conditions have been previously described, with modifications. ${ }^{35,36}$ The primers that were used for PCR were those according to Tohdo et al. $1993{ }^{37}$

\section{LSAB-immunoperoxidase}

Sequential sections of $3 \mu \mathrm{m}$ from formalin-fixed, paraffin-embedded samples were placed on slides previously treated with 3aminopropyltriethoxy-silane (Sigma, A-3648, USA). After deparaffinization in xylene and rehydration in alcohol, antigen retrieval was performed with
$10 \mathrm{mM}$ citric acid $\mathrm{pH} 6.0$ in a pressure cooker for $4 \mathrm{~min}$. Endogenous peroxidase activity was blocked with $6 \%$ $\mathrm{H}_{2} \mathrm{O}_{2}$. Incubation with 1:100 monoclonal antibody anti-p53 clone DO-7 (Dako, M7001, Denmark) in 1\% bovine serum albumin-phosphate buffered solution, was performed for $16 \mathrm{~h}$ at $4{ }^{\circ} \mathrm{C}$. The slides were then incubated for $30 \mathrm{~min}$ at $37^{\circ} \mathrm{C}$ with secondary biotinylated goat anti-mouse/rabbit Ig, followed by incubation for $30 \mathrm{~min}$ at $37{ }^{\circ} \mathrm{C}$ with the complex, streptavidin and biotinylated peroxidase (Dako, K492, Denmark). Slides were developed using 3,3'-diaminobenzidine tetrahydrochloride (Sigma, D-5637, USA), $6 \% \mathrm{H}_{2} \mathrm{O}_{2}$, and dimethyl sulphoxide and counterstained with Harris' hematoxylin. The samples were observed with optic microscope by 2 observers (SN and VAFA) and were scored as previously described by Harvey $^{38}$; estimated proportion and intensity scores were added to obtain a total score that ranged from 0.2 to 8 . A score greater than 2 was used to define p53 positivity.

\section{Statistics}

The statistic analysis was performed with the chi-square and Fisher exact tests using the SPSS 7.5 for Windows, student version. A $P$ value of $<.05$ was considered statistically significant.

\section{RESULTS}

The results of the analysis of PCR products for loss of heterozygosity $(\mathrm{LOH})$ at the $R b, A P C, D C C$, and $p 53$ loci on 22 gastric cancer tissues (13 of intestinal type and 9 of diffuse type) matched with corresponding peripheral leukocytes are listed in Table 2. Heterozygosity was found for $A P C$ in 13 of $21(61.9 \%)$ cases, for $D C C$ in 13 of $22(59 \%)$ cases, for $p 53$ in 11 of 21 $(52.4 \%)$ cases, and for $R b$ in 7 of 19 $(36.8 \%)$ cases. Those cases that had no amplification in leukocyte and tumor DNA for unknown reasons were excluded from this analysis. No LOH was observed in these tumor suppressor genes. Nonetheless, no PCR product was obtained for the tumor DNA when compared to the normal DNA at the DCC gene in 1 patient (CA.6) and at the $R b$ gene in 3 patients (CA.6, CA.11, CA.22), suggesting homozygous deletion.

To confirm homozygous deletion at the $D C C$ and $R b$ genes, a second pair 
Table 2 - p53 protein immunoreactivity to anti-p53, band mobility shift by single strand conformation polymorphism (SSCP) in exons 5-6 and exons 7-8, and analysis of loss of heterozygosity at $A P C, D C C, p 53$, and $R b$ loci in gastric cancer.

\begin{tabular}{|c|c|c|c|c|c|c|c|c|c|c|c|}
\hline Case & Age & Sex & Stage & Histology & Allred & Exons 5-6 & Exons $7-8$ & $A P C$ & $D C C$ & p53 & $R b$ \\
\hline CA.1 & 70 & M & II & Intestinal & $2 p+3 i=5$ & NEG & NEG & INF & $\mathrm{H}$ & INF & INF \\
\hline CA. 2 & 62 & $\mathrm{~F}$ & II & Intestinal & $0+0=0$ & NEG & POS & INF & INF & INF & INF \\
\hline CA. 3 & 77 & M & IIIa & Intestinal & $2 p+1 i=3$ & NEG & POS & $\mathrm{H}$ & $\mathrm{H}$ & INF & $\mathrm{H}$ \\
\hline CA. 4 & 68 & M & II & Diffuse & $5 p+3 i=8$ & NEG & POS & $\mathrm{H}$ & INF & $\mathrm{H}$ & INF \\
\hline CA. 5 & 93 & $\mathrm{~F}$ & IIIb & Intestinal & $2 p+1 i=3$ & NEG & NEG & INF & INF & INF & $\mathrm{H}$ \\
\hline CA. 6 & 73 & M & IIIb & Intestinal & $5 p+3 i=8$ & NEG & POS & INF & $\mathbf{H}^{*}$ & $\mathrm{H}$ & HD \\
\hline CA. 7 & 61 & M & II & Diffuse & $5 p+2 i=7$ & POS & POS & INF & INF & INF & $\mathrm{H}$ \\
\hline CA. 8 & 55 & M & IIIb & Intestinal & $0+0=0$ & NEG & POS & INF & $\mathrm{H}$ & INF & INF \\
\hline CA. 9 & 39 & M & IIIb & Intestinal & $1 p+1 i=2$ & NEG & POS & $\mathrm{H}$ & INF & INF & $\mathrm{H}$ \\
\hline CA. 10 & 72 & M & IVa & Diffuse & $1 p+3 i=4$ & POS & POS & INF & $\mathrm{H}$ & $\mathrm{H}$ & $\mathrm{H}$ \\
\hline CA.11 & 59 & M & II & Intestinal & $1 p+1 i=2$ & NEG & NEG & INF & $\mathrm{H}$ & $\mathrm{H}$ & HD \\
\hline CA.12 & 76 & M & IIIa & Intestinal & $5 p+2 i=7$ & POS & POS & $\mathrm{H}$ & $\mathrm{H}$ & $\mathrm{H}$ & $\mathrm{H}$ \\
\hline CA.13 & 68 & M & II & Intestinal & $2 p+2 i=4$ & NEG & POS & INF & INF & INF & $\mathrm{H}$ \\
\hline CA.14 & 52 & M & IIIa & Diffuse & $4 p+3 i=7$ & NEG & POS & $\mathrm{H}$ & $\mathrm{H}$ & $\mathrm{H}$ & INF \\
\hline CA. 15 & 72 & F & II & Diffuse & $2 p+1 i=3$ & POS & POS & INF & INF & $\mathrm{H}$ & $\mathrm{H}$ \\
\hline CA. 16 & 64 & M & IIIb & Diffuse & $1 p+1 i=2$ & NEG & POS & INF & INF & INF & $\mathrm{H}$ \\
\hline CA. 17 & 73 & M & IVa & Intestinal & $3 p+1 i=4$ & NEG & POS & $\mathrm{H}$ & INF & $\mathrm{H}$ & INF \\
\hline CA.18 & 72 & M & IIIb & Diffuse & $3 p+1 i=4$ & NEG & POS & INF & INF & $\mathrm{H}$ & NA \\
\hline CA. 19 & 40 & F & II & Diffuse & $0+0=0$ & NEG & NEG & $\mathrm{H}$ & INF & $\mathrm{H}$ & NA \\
\hline CA. 20 & 49 & M & II & Diffuse & $0+0=0$ & NEG & POS & NA & $\mathrm{H}$ & NA & NA \\
\hline CA. 21 & 61 & M & II & Intestinal & $4 p+1 i=5$ & NEG & POS & $\mathrm{H}$ & INF & INF & INF \\
\hline CA.22 & 32 & M & Ia & Intestinal & $0+0=0$ & NEG & POS & INF & INF & INF & HD \\
\hline
\end{tabular}

POS = band mobility shift positive; NEG = no band mobility shift; INF = informative case with no LOH; $\mathrm{H}=$ homozygous (no informative); HD = homozygous deletion; $\mathrm{NA}=$ no amplification in leukocyte and tumor DNA; $\mathrm{H}^{*}=$ homozygous for VNTR marker.

of primers that span the same locus was used, a variable number of the tandem repeat markers (VNTR) was used for the $D C C$ gene, and a microsatellite marker (D13S270) was used for the $R b$ gene. Homozygous deletion was confirmed only at the $R b$ gene (Figure 1). These 3 cases of the intestinal-type gastric carcinomas $(3 / 13-23 \%)$ with homozygous deletion at $R b$ gene were classified as stage Ia, stage II, and stage IIIb, respectively.

Since $p 53$ gene alterations are very frequent in gastric cancer and no allelic loss was detected, we decided to search for mutations using PCR analysis for single-strand conformation polymorphism (PCR-SSCP) and p53 protein overexpression using LSABimmunoperoxidase. Eighteen (81.8\%) cases of both histological types showed mobility shifts in exons 5-6 and/or 7-8 of the $p 53$ gene (Figure 2). The $p 53$ protein expression was positive in gastric cancer cells in 14 cases (63.6\%). There was no significant correlation of band mobility shift and im-
CA6 CA11 CA22
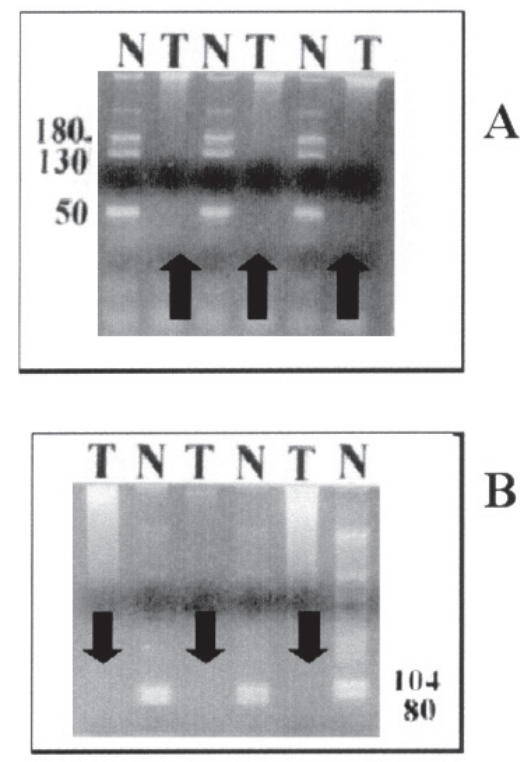

CA11 CA22 CA6

Figure 1 - Homozygous deletion at $R b$ tumor suppressor genes in gastric cancer. DNA band sizes are indicated in numbers of base pairs. N, leukocytes DNA; T, tumor DNA. (A) Cleavage of 180 bp PCR products by BamHI results in fragments 130 and 50 bp long. These three cases (CA.6, CA.11 and CA.22) are heterozygous; however, both alleles are deleted (shown by the arrows), confirmed by microsatellite marker D13S270 (B). munoreactivity to anti-p53 $(P=.90)$. The staining of p53 was never observed in the normal gastric mucosa adjacent to the tumor tissue; thus, p53 protein immunoreactivity likely indicated mutant forms of the $p 53$ gene. The correlation of band mobility shifts and immunoreactivity was not observed in 9 cases. In 7 cases, a mobility shift was detected in exons 7-8 with negative immunoreactivity to anti-p53, 4 were $0+0=0$ and 3 cases were $1 p+1 i=2$. The immunoreactivity to anti-p53 was positive in 2 cases $(2 p+3 i=5 ; 2 p+1 i=3)$ with a negative band mobility shift.

The statistical analysis showed that there was no correlation of sex, age, histology, or severity of disease with mutation and with the immunoreactivity to anti-p53.

\section{DISCUSSION}

To understand the molecular events of gastric carcinogenesis in our envi- 


\section{N T T T T T T N}

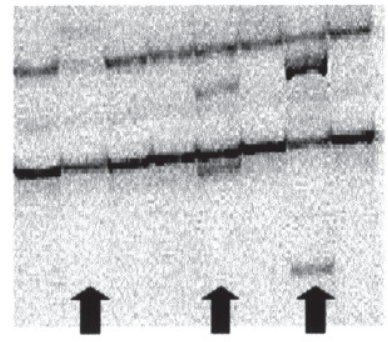

A
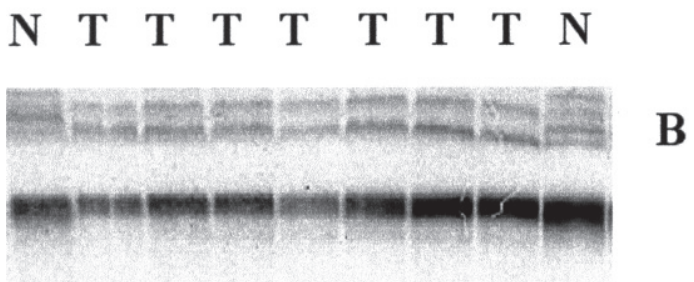

Figure 2 - Polymerase chain reaction analysis for single-strand conformation polymorphism (PCR-SSCP) analysis of gastric cancer tissues and leukocytes. (A) Band mobility sift in exons 56 of the p53 gene indicated by arrow in three cases. (B) All cases shown are presenting band mobility shift in exons $7-8$ of the p53 gene. $\mathrm{N}$, leukocytes DNA; T, tumor DNA.

ronment, the DNA of 22 gastric tumors paired with corresponding DNA of peripheral leukocytes were studied for loss of heterogeneity ( $\mathrm{LOH})$ of the $p 53$, $A P C, D C C$, and $R b$ genes. These tumor suppressor genes were chosen for this study based on previous reports showing that their inactivations have a role in gastric carcinogenesis.

Loss of heterogeneity at the $A P C$ locus was detected in $87 \%$ of primary gastric carcinomas in both intestinal and diffuse types in both early and advanced stages. ${ }^{39}$ Therefore, $\mathrm{LOH}$ at $A P C$ was considered one of the most prevalent genetic alterations in human gastric carcinoma, and it occurred at an early stage of the carcinogenesis and was not a prognostic factor. Moreover, Sano et al. ${ }^{40}$ had observed LOH on chromosome $5 \mathrm{q}$ where the APC gene is located in $60 \%$ of early well-differentiated carcinoma, but not in poorly differentiated carcinoma.

In our study, no $\mathrm{LOH}$ was detected at the $A P C$ locus. Other authors ${ }^{17,41}$ studying the same polymorphic site found a low incidence $(27 \%-30 \%)$ of $\mathrm{LOH}$ in gastric cancer. Also in Africa, where the frequency of gastric cancer is low as it is in Brazil, only 1 patient presented LOH in the $5 \mathrm{q}$ region. ${ }^{42}$ Furthermore, in gastric cancer patients from north-central Italy, no intragenic mutations were found in $A P C$ codons 686 through 1693, and allelic loss was detected in loci near $A P C{ }^{43}$

These authors argued that epidemiologic studies have not observed a higher risk of gastric cancer in patients with inherited familial adenomatous polyposis. Fundic gland polyps are the most common gastric lesion in familial adenomatous polyposis and are generally believed to have little or no potential for malignant transformation in the population at large. The development of high-grade dysplasia or gastric adenocarcinoma associated with diffuse fundic gland polyposis was described in a few cases of familial adenomatous polyposis. ${ }^{44}$ Gastric-type adenomas were less likely to show high-grade dysplasia and adenocarcinoma and were found in 10 patients with familial adenomatous polyposis. ${ }^{45}$

High frequencies of allelic deletions affecting the $D C C$ locus have been previously described to occur in $30 \%{ }^{17}$ to $60 \%{ }^{16}$ of cases of both types of gastric cancer ${ }^{15}$ and more often in advanced (50\%) than in early (14.3\%) disease. Only 1 case in the present study (CA.6) showed what seemed to be homozygous deletion at the $D C C$ gene by RFLP; however, with another pair of primers, a region of the $D C C$ gene was amplified. Thus, the possibility of homozygous deletion was excluded. Since the frequency of $D C C$ loss is higher in advanced disease and more frequent in the intestinal type, we were expecting that at least in the 5 cases that had advanced intestinaltype gastric cancer and were informative for $D C C$ gene, loss would be found.

Homozygous deletion at the $R b$ gene was detected in $3(3 / 13-23 \%)$ cases of the intestinal-type gastric cancer, which seems to be an early event, since 2 of these patients had initial disease (stage Ia and stage II). The inactivation of the $R b$ gene by mutation or loss has been considered an important genetic alteration in esophageal carcinogenesis. ${ }^{26,31}$ Our data suggest that $R b$ gene inactivation may be involved in the development and/or progression of intestinal-type gastric cancer.

Homozygous deletions are thought to be the result of 2 events: the loss of a larger chromosomal region and the independent loss of a considerably smaller area. ${ }^{46}$ In previous reports, homozygous deletion was described in a variety of cancers as a mechanism of total gene inactivation, and the presence of at least 1 tumor suppressor gene within the deleted region was suggested. ${ }^{47-50}$

A higher prevalence $(30 \%)$ of $R b$ $\mathrm{LOH}$ in both histological types of gastric cancer was found by other authors. ${ }^{17} \mathrm{~A}$ more recent report ${ }^{51}$ showed that the mRNA levels of $R b$ and $p 53$ in gastric cancer tissues were both significantly lower than were those in their noncancerous tissue samples. 
These studies indicate that the suppression of both $R b$ and $p 53$ may be associated with the tumorigenesis of the stomach.

Loss of heterozygosity on chromosome $17 \mathrm{p}$ (p53 locus) and mutation of the $p 53$ gene have been observed in more than $60 \%$ of gastric carcinomas, regardless of the histological type, ${ }^{40}$ and have been correlated with short survival times. ${ }^{9}$ Surprising, no $\mathrm{LOH}$ at the $p 53$ gene was observed in our cases. One possible explanation for the fact that we did not find $\mathrm{LOH}$ at $p 53$ gene may be that this gene may be altered through another mechanism, such as point mutation. To search for p53 gene mutations, we decided to use PCR-SSCP and to correlate with immunoreactivity to anti-p53. The half-life of wild-type $p 53$ is short, around 20 to 30 minutes; consequently, p53 protein expression usually is negative in normal tissues. Mutations render the p53 protein to be a more stable compound with a longer half-life $(1.5-7 \mathrm{~h}){ }^{52}$ Thus, $p 53$ protein overexpression is likely to represent mutant forms..$^{53}$

In the literature, the authors usually employ ${ }^{32} \mathrm{P}$-dCTP for PCR-SSCP ${ }^{35,36}$; however, ${ }^{32} \mathrm{P}$ is a high-energy $\beta$ particle emitter, so we decided to try the low-energy $\beta$ particle emitter, ${ }^{35} \mathrm{~S}$ dATP. The bands were easily visualized in dried gels exposed at $-80^{\circ} \mathrm{C}$ for at least 3 days. Thus, the use of ${ }^{35} \mathrm{~S}$ dATP was more advantageous than ${ }^{32} \mathrm{P}$ dATP, since it lowered the risk for the personnel of the lab.

Following PCR-SSCP, band mobility shifts were observed mainly in exons 7-8 (86.36\%) that encompasses codons 225 to 326 . Other authors ${ }^{54}$ studying $p 53$ in gastric cancer also found a predominance of mutations in exons 7-8 (70\%).

Non-missense mutations or frameshifts could explain negative immunoreactivity with band mobility shifts in 7 cases. Moreover, analyzing the Allred criteria only 4 were truly negative $0+0=0$, and 3 cases were $1 \mathrm{p}+1 \mathrm{i}=2$ (considered negative). Allred 2 should be better evaluated and, perhaps, considered as positive for $p 53$ expression as determined by immunohistochemistry. Seta et al., $1998^{54}$ found a $p 53$ mutation in 2 cases of gastric cancer with less than $25 \%$ of cells positive $(+)$ by immunohistochemistry. Assuming Allred 2 to be positive for $\mathrm{p} 53$, the agreement of immunohistochemistry and PCR-SSCP would be $72.7 \%$.

In 2 cases that had immunoreactivity to anti-p53 and most probably harbored mutation in the $p 53$ gene, PCR-SSCP was unable to detect mutation. A discrepancy between results by PCR-SSCP and DNA sequencing has been reported in the literature. In MKN-7 and MKN-28 gastric cancer cell lines, $p 53$ gene mutations were not detected by PCR-SSCP ${ }^{36}$; however, point mutations at codons 278 and 251 , respectively, were found by cDNA sequencing. ${ }^{53}$

In conclusion, the inactivation of p53 is involved in the development and/or progression of both diffuse and intestinal types of gastric cancer. However, loss of the $R b$ gene plays role only in the intestinal-type gastric cancer progression. It has been suggested that $H$. pylori infection initiates gastric cancer through $p 53-R b$ tumor-suppressor system mutation and telomerase reactivation. ${ }^{27}$ Even though the incidence of $H$. pylori in the normal population of Brazil is high (80\%), the association of $H$. pylori infection and gastric cancer has been observed exclusively with the intestinal type ( $P$ $=.008)^{55}$. Further studies are needed to demonstrate the direct involvement of H. pylori in $p 53$ and $R b$ gene inactivation in our cases of gastric cancer.

\section{ACKNOWLEDGEMENTS}

The authors thank Ana Maria Alexandrino for doing PCR-LOH of the cases.

\section{RESUMO}

MATTAR R e col. Alterações dos genes supressores tumorais $p 53$ e $R b$ no câncer gástrico. Rev. Hosp. Clín. Fac. Med. S. Paulo 59(4):172-180, 2004.

A inativação de genes supressores tumorais tem sido freqüentemente observada na carcinogênese gástrica. $\mathrm{O}$ nosso objetivo foi estudar o envolvimento dos genes $p 53, A P C, D C C$ e $R b$ no câncer gástrico.

MÉTODO: Vinte e dois casos de câncer gástrico foram estudados por PCR-LOH (reação de polimerase em cadeia- perda de alelo heterozigoto) dos genes $p 53, A P C, D C C$ e $R b$; e por PCR-SSCP (reação de polimerase em cadeia- polimorfismo de conformação de cadeia única) dos exons 5-6 e exons 7-8 do gene p53, empregando ${ }^{35} \mathrm{~S}-$ dATP e expressão de p53 por imunoperoxidase com monoclonal anti-p53.

RESULTADOS E DISCUSSÃO: Perda de alelo heterozigoto não foi detectada nos genes estudados; deleção 
homozigótica foi observada no gene $R b$ em $23 \%$ (3/13) dos casos de câncer gástrico do tipo intestinal. Desvio de motilidade de banda nos exons 5-6 e/ou exons 7-8, indicando mutação do gene $p 53$ foi encontrada em 18 casos (81.8\%). A expressão de p53 foi positiva nas células de câncer gástrico em 14 casos $(63.6 \%)$. A mucosa gástrica normal não corou com anti-p53, por- tanto, a reatividade imune deve representar formas mutantes. A correlação de desvio de motilidade de banda e expressão imune de p53 não foi significante $(\mathrm{p}=0.90)$. Não houve correlação entre as alterações genéticas e a extensão da doença.

CONCLUSÃO: A inativação dos genes $p 53$ e $R b$ tem papel na carcinogênese gástrica no nosso meio. A perda do gene $R b$ observada apenas no câncer gástrico do tipo intestinal deve ser avaliada posteriormente em associação com infecção pelo Helicobacter pylori. O gene p53 estava afetado em ambos os tipos histopatológicos.

UNITERMOS: Câncer gástrico. p53. APC. DCC. Rb.

\section{REFERENCES}

1. Laurén P. The two histological main types of gastric carcinoma: diffuse and so-called intestinal-type. Acta Pathol Microbiol Scand 1965;64:31-49.

2. Hirohashi S, Sugimura T. Genetic alterations in human gastric cancer. Cancer Cells 1991;3:49-52.

3. Tahara E. Molecular mechanism of stomach carcinogenesis. J Cancer Res Clin Oncol 1993;119:265-72.

4. Yasui W, Yokozaki H, Fujimoto J, Naka K, Kuniyasu H, Tahara E. Genetic and epigenetic alterations in multistep carcinogenesis of the stomach. J. Gastroenterol 2000;35:111-5.

5. Lee HS, Lee HK, Kim HS, Yang HK, Kim WH. Tumour suppressor gene expression correlates with gastric cancer prognosis. J Pathol 2003;200:39-46.

6. Maehara Y, Tomoda M, Hasuda S, Kabashima A, Tokunaga E, Kakeji Y, et al. Prognostic value of p53 protein expression for patients with gastric cancer- a multivariate analysis. $\mathrm{Br} \mathrm{J}$ Cancer 1999;79:1255-61.

7. Baldus SE, Schneider PM, Monig SP, Zirbes TK, Fromm S, Meyer $\mathrm{W}$, et al. p21/waf1/cip1 in gastric cancer: associations with histopathological subtypes, lymphonodal metastasis, prognosis and p53 status. Scand J Gastroenterol 2001;36:975-80.

8. Kataoka M, Okabayashi T, Johira H, Nakatani S, Nakashima A, Takeda A, et al. Aberration of p53 and DCC in gastric and colorectal cancer. Oncol Rep 2000; 7:99-103.

9. Lee WJ, Shun CT, Hong RL, Wu MS, Chang KJ, Chen KM. Overexpression of $\mathrm{p} 53$ predicts shorter survival in diffuse type-gastric cancer. Br J Surg 1998;85:1138-42.

10. Kubicka S, Claas C, Staab S, Kuhnel F, Zender L, Trautwein C, et al. p53 mutation pattern and expression of c-erbB2 and c-met in gastric cancer: relation to histological subtypes, Helicobacter pylori infection, and prognosis. Dig Dis Sci 2002;47:114-21.

11. Kastan MB, Onyekwere O, Sidransky D, Vogelstein B, Craig RW. Participation of $\mathrm{p} 53$ protein in the cellular response to DNA damage. Cancer Res 1991;51:6304-11.
12. Chen J, Jackson PK, Kirschner MW, Dutta A. Separate domains of p21 involved in the inhibition of Cdk kinase and PCNA. Nature $1995 ; 374: 386-8$

13. Waga S, Hannon GJ, Beach D, Stillman B. The p21 inhibitor of cyclin-dependent kinases controls DNA replication by interaction with PCNA. Nature 1994;369:574-8.

14. Miyashita T, Reed JC. Tumor suppressor p53 is a direct transcriptional activator of the human bax gene. Cell 1995;80:293-9

15. Fang DC, Jass JR,Wang DX. Loss of heterozygosity and loss of expression of the DCC gene in gastric cancer. J Clin Pathol 1998;51:593-6

16. Uchino S, Tsuda H, Noguchi M, Yokota J, Terada M, Saito T, et al. Frequent loss of heterozygosity at the DCC locus in gastric cancer. Cancer Res 1992;52:3099-102.

17. Cho JH, Noguchi M, Ochiai A, Hirohashi S. Loss of heterozygosity of multiple tumor suppressor genes in human gastric cancers by polymerase chain reaction. Lab Invest 1996;74:835- 41 .

18. Candusso ME, Luinetti O, Villani L, Alberizzi P, Klersy C, Fiocca $\mathrm{R}$, et al. Loss of heterozygosity at $18 \mathrm{q} 21$ region in gastric cancer involves a number of cancer-related genes and correlates with stage and histology, but lacks independent prognostic value. J Pathol 2002;197:44-50.

19. Fearon ER, Cho KR, Nigro JM, Kern SE, Simons JW, Ruppert $\mathrm{JM}$, et al. Identification of a chromosome 18q gene that is altered in colorectal cancers. Science 1990;247:49-56.

20. Cooper HM, Gad JM, Keeling SL. The Deleted in Colorectal Cancer netrin guidance system: a molecular strategy for neuronal navigation. Clin Exp Pharmacol Physiol 1999;26:749-51.

21. Chen YQ, Hsieh JT, Yao F, Fang B, Pong RC, Cipriano SC, et al Induction of apoptosis and G2/M cell cycle arrest by DCC. Oncogene 1999;18:2747-54.

22. Nishisho I, Nakamura Y, Miyoshi Y, Miki Y, Ando H, Horii A, et al. Mutations of chromosome 5q21 genes in FAP and colorectal cancer patients. Science 1991;253:665-9. 
23. Wu LB, Kushima R, Borchard F, Molsberger G, Hattori T. Intramucosal carcinomas of the stomach: phenotypic expression and loss of heterozygosity at microsatellites linked to the APC gene. Pathol Res Pract 1998;194:405-11.

24. Kolligs FT, Bommer G, Goke B. Wnt/beta-catenin/tcf signaling: a critical pathway in gastrointestinal tumorigenesis. Digestion 2002;66:131-44

25. Ebert MP, Fei G, Kahmann S, Muller O, Yu J, Sung JJ, et al. Increased beta-catenin mRNA levels and mutational alterations of the APC and beta-catenin gene are present in intestinal-type gastric cancer. Carcinogenesis 2002;23:87-91.

26. Xing EP, Yang GY, Wang LD, Shi ST, Yang CS. Loss of heterozygosity of the $\mathrm{Rb}$ gene correlates with $\mathrm{pRb}$ protein expression and associates with p53 alteration in human esophageal cancer. Clin Cancer Res 1999;5:1231-40.

27. Lan J, Xiong YY, Lin YX, Wang BC, Gong LL, Xu HS, et al. Helicobacter pylori infection generated gastric cancer through $\mathrm{p} 53-\mathrm{Rb}$ tumor-suppressor system mutation and telomerase reactivation. World J Gastroenterol $2003 ; 9: 54-8$

28. Strobeck MW, Knudsen KE, Fribourg AF, DeCristofaro MF, Weissman BE, Imbalzano AN, et al. BRG-1 is required for RBmediated cell cycle arrest. Proc Natl Acad Sci USA 2000;97:7748-53

29. Japanese Research Society for Gastric Cancer - Japanese classification of gastric carcinoma. Tokyo: Kanehara \& Co. Ltda., 1995.

30. Sambrook J, Fritsch EF, Maniatis T. Isolation of high-molecularweight DNA from mammalian cells. In:Molecular Cloning- A Laboratory Manual, $2^{\text {nd }}$ ed. New York:Cold Spring Harbor Laboratory, 1989. p. 9.14-9.19

31. Huang Y, Boynton RF, Blount PL, Silverstein RJ, Yin J, Tong Y, et al. Loss of heterozygosity involves multiple tumor suppressor genes in human esophageal cancers. Cancer Res 1992;52:652530 .

32. de la Calle-Martin O, Fabregat V, Romero M, Soler J, Vives J, Yague J. AccII polymorphism of the p53 gene. Nucleic Acids Res 1990;18:4963.

33. Goto A, Kanda H, Ishikawa Y, Matsumoto S, Kawaguchi N, Machinami R, et al. Association of loss of heterozygosity at the p53 locus with chemoresistance in osteosarcomas. Jpn J Cancer Res 1998;89:539-47.

34. Bookstein R, Lai CC, To H, Lee WH. PCR-based detection of a polymorphic BamHI site in intron 1of the human retinoblastoma (RB) gene. Nucleic Acids Res 1990;18:1666.

35. Mazars R, Pujol P, Maudelonde T, Jeanteur P, Theillet C. p53 mutations in ovarian cancer: a late event? Oncogene 1991;6:1685-190.

36. Yamada Y, Yoshida T, Hayashi K, Sekiya T, Yokota J, Hirohashi S, et al. p53 gene mutations in gastric cancer metastases and in gastric cancer cell lines derived from metastases. Cancer Res 1991;51:5800-05.

37. Tohdo H, Yokozaki H, Haruma K, Kajiyama G, Tahara E. p53 gene mutations in gastric adenomas. Virchows Arch B Cell Pathol 1993;63:191-5.
38. Harvey JM, Clark GM, Osborne CK, Allred DC. Estrogen receptor status by immunohistochemistry is superior to the ligandbinding assay for predicting response to adjuvant endocrine therapy in breast cancer. J Clin Oncol 1999;17:1474-81.

39. Sanz-Ortega J, Sanz-Esponera J, Caldes T, Gomez de la Concha E, Sobel ME, Merino MJ. LOH at the APC/MCC gene (5q21) in gastric cancer and preneoplastic lesions. Prognostic implications. Pathol Res Pract 1996;192:1206-10.

40. Sano T, Tsujino T, Yoshida K, Nakayama H, Haruma K, Ito H, et al. Frequent loss of heterozygosity on chromosomes 1q, 5q, and 17p in human gastric carcinomas. Cancer Res 1991; $51: 2926-31$

41. Semba S, Yokozaki H, Yamamoto S, Yasui W, Tahara E. Microsatellite instability in precancerous lesions and adenocarcinomas of the stomach. Cancer 1996;77:1620-27.

42. Chetty R, Naidoo R, Tarin M, Sitti C. Chromosome 2p, 3p, 5q and $18 \mathrm{q}$ status in sporadic gastric cancer. Pathology 2002;34:27581 .

43. Powell SM, Cummings OW, Mullen JA, Asghar A, Fuga G, Piva P, et al. Characterization of the APC gene in sporadic gastric adenocarcinomas. Oncogene 1996;12:1953-9.

44. Hofgartner WT, Thorp M, Ramus MW, Delorefice G, Chey WY, Ryan CK, et al. Gastric adenocarcinoma associated with fundic gland polyps in a patient with attenuated familial adenomatous polyposis. Am J Gastroenterol 1999;94:2275-81.

45. Abraham SC, Montgomery EA, Singh VK, Yardley JH, Wu TT. Gastric adenomas: intestinal-type and gastric-type adenomas differ in the risk of adenocarcinoma and presence of background mucosal pathology. Am J Surg Pathol 2002;26:1276-85

46. Hahn SA, Schutte M, Hoque AT, Moskaluk CA, da Costa LT, Rozenblum E, et al. DPC4, a candidate tumor-suppressor gene at $18 \mathrm{q} 21.1$. Science $1996 ; 271: 350-3$

47. Hatta Y, Hirama T, Miller CW, Yamada Y, Tomonaga M, Koeffler HP. Homozygous deletions of the p15 (MTS2) and p16 (CDKN2/MTS1) genes in adult T-cell leukemia. Blood $1995 ; 85: 2699-704$

48. Hahn SA, Hoque AT, Moskaluk CA, da Costa LT, Schutte M, Rozenblum E, et al. Homozygous deletion map at 18q21.1 in pancreatic cancer. Cancer Res 1996;56:490-4.

49. Sundaresan V, Chung G, Heppell-Parton A, Xiong J, Grundy C, Roberts I, et al. Homozygous deletions at 3 p12 in breast and lung cancer. Oncogene 1998;17:1723-9.

50. Chandramohan SI, Shuster M, Bockmühl U, Thakker N, Shah P, Toomes C, et al. Frequent allelic loss and homozygous deletion in chromosome band 8p23 in oral cancer. Int J Cancer 1999;80:25-31.

51. Chen YJ, Shih LS, Chen YM. Quantitative analysis of CDKN2, p53 and retinoblastoma mRNA in human gastric carcinoma. Int J Oncol 1998;13:249-54.

52. Hinds PW, Finlay CA, Quartin RS, Baker SJ, Fearon ER, Vogelstein $\mathrm{B}$, et al. Mutant p53 DNA clones from human colon carcinomas cooperate with ras in transforming primary rat cells: a comparison of the hot spot mutant phenotypes. Cell Growth Different 1990;1:571-80 
$p 53$ and $R b$ tumor suppressor gene alterations in gastric cancer Mattar R et al.

53. Mattar R, Yokozaki H, Yasui W, Ito H, Tahara E. p53 gene mutations in gastric cancer cell lines. Oncol. (Life Sci. Adv.) 1992;11:712 .

54. Seta T, Imazeki F, Yokosuka O, Saisho H, Suzuki T, Koide Y, et al. Expression of p53 and p21waf1/cip1 proteins in gastric and esophageal cancers: comparison with mutations of the p53 gene. Dig Dis Sci 1998;43(2):279-89.
REV. HOSP. CLÍN. FAC. MED. S. PAULO 59(4):172-180, 2004

55. Mattar R, Silva FM, Birbojm I, Zilberstein B, Gama-Rodrigues JJ. Helicobacter pylori infection: a risk factor for gastric cancer? a serological study. Proceedings of the $5^{\text {th }}$ International Gastric Cancer. 2003. p.17. 